\title{
Evaluation of Medicinal Plant Hepatotoxicity in Co-cultures of Hepatocytes and Monocytes
}

\author{
Bashar Saad ${ }^{1,2}$, Suha Dakwar', Omar Said1, Ghassan Abu-Hijleh², Feras Al Battah², \\ Abedelsalam Kmeel $^{2}$ and Hassan Aziazeh ${ }^{1}$
}

${ }^{1}$ Research and Development Regional Center (affiliated with Haifa University, Haifa Israel)—The Galilee Society, PO Box 437, Shefa Amr 20200, Israel and ${ }^{2}$ Faculty of Allied Medical Sciences, The Arab American University

Jenin, PO Box 240, Jenin, Palestine

\begin{abstract}
Non-parenchymal cells might play an important role in the modulation of xenobiotic metabolism in liver and its pharmacological and toxicological consequences. Therefore, the role of cell-to-cell interactions in herbal induced liver toxicity was investigated in monocultures of cells from the human hepatocyte cell line (HepG2) and in co-cultures of cells from the HepG2 cell line and cells from the human monocyte cell line (THP1). Cells were treated with various concentrations $\left(1-500 \mu \mathrm{g} \mathrm{m}^{-1}\right)$ of extracts of Pistacia palaestina, Juglans regia and Quercus ithaburensis for $24 \mathrm{~h}$. Extracts from Cleome droserifolia, a known toxic plant, were taken as positive control. In the co-culture system, toxic effects were observed after exposure to extracts of Pistacia palestina and $C$. droserifolia. These two extracts significantly reduced by cell viability as measured the MTT test and the LDH assay. Whereas in hepatocyte cultures, only extracts of $C$. droserifolia were found to affect the cell viability. The production levels of albumin from hepatocytes were not affected by treatment with plant extracts in both culture systems. It seems that the observed reduction in cell viability after exposure to extracts of $P$. palestina in co-cultures but not in monocultures is a result of monocyte-derived factors. The use of liver cell co-cultures is therefore a useful approach to investigate the influence of intercellular communication on xenobiotic metabolism in the liver.
\end{abstract}

Keywords: biosafety - co-cultures - hepatocyte - in vitro - medicinal plants

\section{Introduction}

The currently observed rapid increase in consumption of herbal remedies worldwide has been stimulated by several factors, including the notion that all herbal products are safe and effective (1-3). However, over the past decade, several news-catching episodes in developed communities indicated adverse effects, sometimes life-threatening, allegedly arising consequential to taking herbal products or traditional medicines from various ethnic groups $(4,5)$. In some cases, adulteration, inappropriate formulation, or lack of

For reprints and all correspondence: Prof. Dr Bashar Saad, Research and Development Regional Center-The Galilee Society, PO Box 437,

Shefa Amr 20200, Israel. Tel: +972-4-950-45-23; Fax: +972-4-950-45-25;

E-mail: bsaad@gal-soc.org understanding of plant and drug interactions or uses has led to adverse reactions that are sometimes life-threatening or lethal to patients (6-10).

\section{Hepatotoxicity of Herbal Remedies}

Most reports of toxic effects due to the use of herbal medicines and dietary supplements are associated with hepatotoxicity although reports of other toxic effects including kidney, nervous system, blood, cardiovascular and dermatologic effects, mutagenicity, and carcinogenicity have also been published in medical literature. On the basis of various case reports, liver injury from herbal remedies has ranged from mild elevations of liver enzymes to fulminated liver failure requiring liver transplantation. The reported toxicity of herbal formulations may be the result of several factors, including

(C) The Author (2006). Published by Oxford University Press. All rights reserved.

The online version of this article has been published under an open access model. Users are entitled to use, reproduce, disseminate, or display the open access version of this article for non-commercial purposes provided that: the original authorship is properly and fully attributed; the Journal and Oxford University Press are attributed as the original place of publication with the correct citation details given; if an article is subsequently reproduced or disseminated not in its entirety but only in part or as a derivative work this must be clearly indicated. For commercial re-use, please contact journals.permissions@ oxfordjournals.org 
contamination with pesticides, microbes, heavy metals, toxins or adulteration with orthodox drugs (11). Therefore, for safety and quality assurances, chemical analytical techniques should be applied at different stages for good practices in quality assurances of natural or herbal products, including good agricultural practice by farmers, good sourcing and laboratory practices by pharmaceutical companies, good manufacturing practices and innovative clinical trial practices by researchers and physicians (5).

\section{In Vitro Test Methods}

In vitro culture models that employ human liver cells could be potent tools for predictive studies on drug toxicity and metabolism in the pharmaceutical industry. In general, in vitro test systems represent the first phase of the evaluation procedure. In the in vitro test systems, cells isolated from various tissues or cell lines are cultured $(12,13)$. In vitro cell culture methods have the advantage of relatively well-controlled variables and are generally accepted as a very effective method for safety testing. Advantages of these systems over classical methods (such as long-term studies on experimental animals) include relatively well-controlled variables, decreased costs, a reduced time to completion and reduced numbers of animals necessary to complete the study. The fact that cells and tissues in vivo do not exist in isolation, but communicate with and are interdependent on neighboring tissue makes it essential to simulate the in vivo situation, where, for example, the microenvironment of the hepatocytes within the liver acinus involves gradients in oxygen tension, hormones, extracellular matrix components, non-parenchymal cells and effective exposure levels of xenobiotics from the periportal to the pericentral compartment $(14,15)$. In addition to primary cultures, cell lines, such as HepG2 (express hepatocyte specific function, such as $\mathrm{P} 450$ and albumin production), provide an adequate in vitro liver model for many mechanistic studies of signal transduction, gene expression, metabolism and toxicology.

\section{Co-cultures of Parenchymal and Non-parenchymal Cells}

Conventional homotypic hepatocyte cultures do not include the possible contribution of non-parenchymal liver cells, particularly Kupffer cells, to the pharmacological and toxicological consequences after exposure to xenobiotics. Therefore, in the present study we evaluated the hepatotoxicity of three plant extracts using co-cultures of cells from the human hepatocyte cell line (HepG2) and cells from the human monocyte cell line (THP1). In this co-culture system both cell types have direct cell-to-cell contacts and are maintained in more 'in vivo-like' culture conditions than in the monoculture system. Results obtained here indicate that one out of three tested plant extracts significantly reduced cell viability in the co-culture system but not in the monoculture system. It seems that the observed reduction in cell viability is a result of monocyte-derived factors.

\section{Material and Methods}

\section{Preparation of Plant Extracts}

Fifty grams of air-dried Pistacia palaestina (leaves), Juglans regia (leaves), Quercus ithaburensis (fruits) and Cleome droserifolia (taken as positive control) were added to 1 liter of distilled water and boiled for $10 \mathrm{~min}$. The boiled water extracts were filtered through filter paper and freezedried in a lyophilizer. The freeze-dried extracts were stored at $-70^{\circ} \mathrm{C}$ for further evaluation.

\section{Cell Culture}

The effect of $P$. palaestina (RDC 1089), J. regia (RDC 1060), $Q$. ithaburensis (RDC 1097) and C. droserifolia (1) on cell viability was assessed in a cell culture system using cells from the human hepatoplastoma cell line HepG2 and cells from the monocyte cell line THP1. HepG2 cell line retains differentiated parenchymal functions of normal hepatocytes, including the expression of P450 isoenzymes (16) thus permitting long-term studies to be performed. The cells from both cell lines were grown in Dulbecco's modified Eagle's medium (DMEM) with a high glucose content $\left(4.5 \mathrm{~g} \mathrm{l}^{-1}\right)$ supplemented with $10 \% \mathrm{vol} / \mathrm{vol}$ inactivated fetal calf serum, $1 \%$ nonessential amino acids, $1 \%$ glutamine, $100 \mathrm{U} \mathrm{ml}^{-1}$ penicillin, and $10 \mu \mathrm{g} \mathrm{ml}^{-1}$ streptomycin. Cells were maintained in humidified atmosphere with $5 \% \mathrm{CO}_{2}$ at $37^{\circ} \mathrm{C}$. The medium of cells from both cell lines was changed twice a week. At 70-80\% confluence, cells were trypsinized and seeded in 96-well plates in cell density of $1.5 \times 10^{4} \mathrm{HepG} 2$ cells and $5 \times 10^{3}$ THP1 cells. Twenty-four hours after cell seeding, cells were exposed to various concentrations of the plant extracts in fresh serum-free medium.

\section{MTT Assay}

The tetrazolium dye, MTT, is widely used to assess the viability and/or the metabolic state of cells (17). This colorimetric assay is based on the conversion of the yellow tetrazolium bromide (MTT) to the red formazan derivative by mitochondrial succinate dehydrogenase in viable cells. Twenty-four hours after cell seeding, cells were incubated with varying concentrations of water extracts of the three plants for $24 \mathrm{~h}$ at $37^{\circ} \mathrm{C}$. Following removal of the plant extracts from each well, cells were washed in phosphate-buffered saline. The cells were then incubated in serum-free DMEM to which MTT $\left(0.5 \mathrm{mg} \mathrm{ml}^{-1}\right)$ was added to each well $(100 \mu \mathrm{l})$, and incubated for a further $4 \mathrm{~h}$. Then the medium was removed and the cells were incubated for $15 \mathrm{~min}$ with $100 \mu \mathrm{l}$ of acidic isopropanol $(0.08 \mathrm{~N} \mathrm{HCl})$ to dissolve the formazan crystals. The absorbance of the MTT formazan was determined at $570 \mathrm{~nm}$ in an enzyme-linked immunosorbent assay (ELISA) reader. Viability was defined as the ratio (expressed as a percentage) of absorbance of treated cells to untreated cells. 


\section{Lactate Dehydrogenase}

In the lactate dehydrogenase (LDH) assay, leakage of the cytoplasmic located enzyme LDH into the extracellular medium is measured. The presence of the exclusively cytosolic enzyme, $\mathrm{LDH}$, in the cell culture medium is indicative of cell membrane damage (17).

For the LDH assay, $1.5 \times 10^{4}$ HepG2 cells and $5 \times 10^{3}$ THP1 were seeded per well of 96-microtiter plates. Twentyfour hour after cell seeding, cells were exposed to varying concentrations of the plant extracts $\left(0.001-0.5 \mathrm{mg} \mathrm{ml}^{-1}\right)$. After $24 \mathrm{~h}$ of treatment, the supernatants were collected from each well. Cell monolayers were then treated with a cell lysis solution for $30 \mathrm{~min}$ at room temperature to lyse. The cells and the lysate were collected. LDH activity was measured in both the supernatants and the cell lysate fractions using CytoTox 96, a non-radioactive cytotoxicity assay kit (Promega, WI, USA), in accordance with the manufacturer's instruction. The intensity color is proportional to LDH activity. The absorbance is determined at $490 \mathrm{~nm}$ with 96-well plate ELISA reader. The percent of $\mathrm{LDH}$ release from the cells was determined using the following formula: $\mathrm{LDH}$ release $=($ Absorbance of the supernatant $) /($ absorbance of the supernatant and cell lysate $) \times 100$.

\section{Quantification of Albumin Secretion}

For the determination of albumin levels in culture supernatants, $1.5 \times 10^{4}$ HepG2 cells and $5 \times 10^{3}$ THP1 were seeded in 96-microtiter plates. Twenty-four hours after cell seeding, cells were exposed to varying concentrations of the plant extracts $\left(0.001-0.5 \mathrm{mg} \mathrm{ml}^{-1}\right)$. After $24 \mathrm{~h}$ of treatment, the supernatants were collected from each well. The amount of albumin in the culture supernatant was measured using ELISA. In brief, supernatants were incubated in 96-well microtiter plates for $1 \mathrm{~h}$ at $37^{\circ} \mathrm{C}$ or overnight at $4^{\circ} \mathrm{C}$. After washing in PBS, non-specific binding sites were blocked in PBS containing $0.5 \%$ bovine serum albumin (BSA) for $1 \mathrm{~h}$ at room temperature. After another washing step in PBS, peroxidase-conjugated goat anti-rat albumin antibody was added in PBS containing 1\% BSA and incubated for $2 \mathrm{~h}$ at room temperature (this antibody cross-reacts with human albumin). The microtiter plates were then washed, the substrate $(0.5 \mathrm{mg}$ 2.2-azino-di-3-ethylbenzothiazoline-6-sulfonic acid per $\mathrm{ml}$ of $100 \mathrm{mM}$ sodium acetate, $50 \mathrm{mM}$ sodium phosphate and $9 \times 10^{-3} \% \mathrm{H}_{2} \mathrm{O}_{2}$ ) added and the absorption was measured at $405 \mathrm{~nm}$ in an ELISA reader. All washing steps were carried out with PBS at room temperature. Background values were measured in the absence of culture supernatant and subtracted from the experimental values. All ELISA determinations were carried out in duplicates.

\section{Statistical Analysis}

Error limits cited and error bars plotted represent simple standard deviations of the mean. Usually, numerical results are only accurate enough to specify the least significant digit. When comparing different samples, results were considered to be statistically different when $P<0.05$ (Student's $t$-test for unpaired samples).

\section{Results}

The effect of extracts of $P$. palaestina, J. regia, $Q$. ithaburensis and $C$. droserifolia was evaluated here in co-cultures of cells from the hepatocyte cell line HepG2 and cells from the monocyte cell line THP1. MTT, LDH assay and albumin determination (ELISA) were carried out $24 \mathrm{~h}$ after treatment with increasing concentrations (1-500 $\mu \mathrm{g} \mathrm{ml}^{-1}$ of culture medium) of extracts from the four plants.

\section{Evaluation of Effects on Cell Viability Using MTT Test}

Metabolic activity can be evaluated by measuring the activity of a mitochondrial enzyme succinate dehydrogenase using MTT test. MTT is designed to be used for the quantification of both cell proliferation and cell viability in cell population using 96-well plate format. This test is widely used in the in vitro evaluation of the biosafety of plant extracts. In the present study we applied the MTT test to evaluate the biosafety of three medicinal plants in hepatocyte monolayers and in co-cultures of hepatocytes and monocytes. Therefore, HepG2 cells and co-cultures of HepG2 and THP1 were exposed to increasing concentrations (1-500 $\mathrm{g} \mathrm{ml}^{-1}$ of culture medium) of the three plant extracts for $24 \mathrm{~h}$. Following removal of the plant extracts from each well, cells were washed in phosphate-buffered saline, and the MTT assay was carried out as described. Unattached HepG2 cells and THP1 cells (grow in suspension) are removed from the co-cultures during the washing process.

\section{HepG2 Cells}

Extracts from $Q$. ithaburensis exhibited no sign of any negative effects at all concentrations tested (Fig. 1A). Extracts from $J$. regia and $P$. palaestina reduced MTT formation by about $60 \%$ at concentration of $500 \mu \mathrm{g} \mathrm{ml} \mathrm{m}^{-1}$ (Fig. 1A). Cell viability was decreased with increasing extract concentrations of $C$. droserifolia, which was taken as a positive control. The cell viability was decreased by about $60 \%$ at $500 \mu \mathrm{g}$ of C. droserifolia per $\mathrm{ml}$.

\section{Co-cultures of HepG2 with THP1}

No sign of any negative effect at all concentrations tested in the co-culture system was seen after exposure to extracts from $J$. regia and $Q$. ithaburensis (Fig. 1B). Cell viability with $P$. palestina was enhanced in the co-cultures. Exposure to Pistacia palestina extracts for $24 \mathrm{~h}$ dose-dependently decreased cell viability, reaching about $20 \%$ of untreated cells (Fig. 1B). 

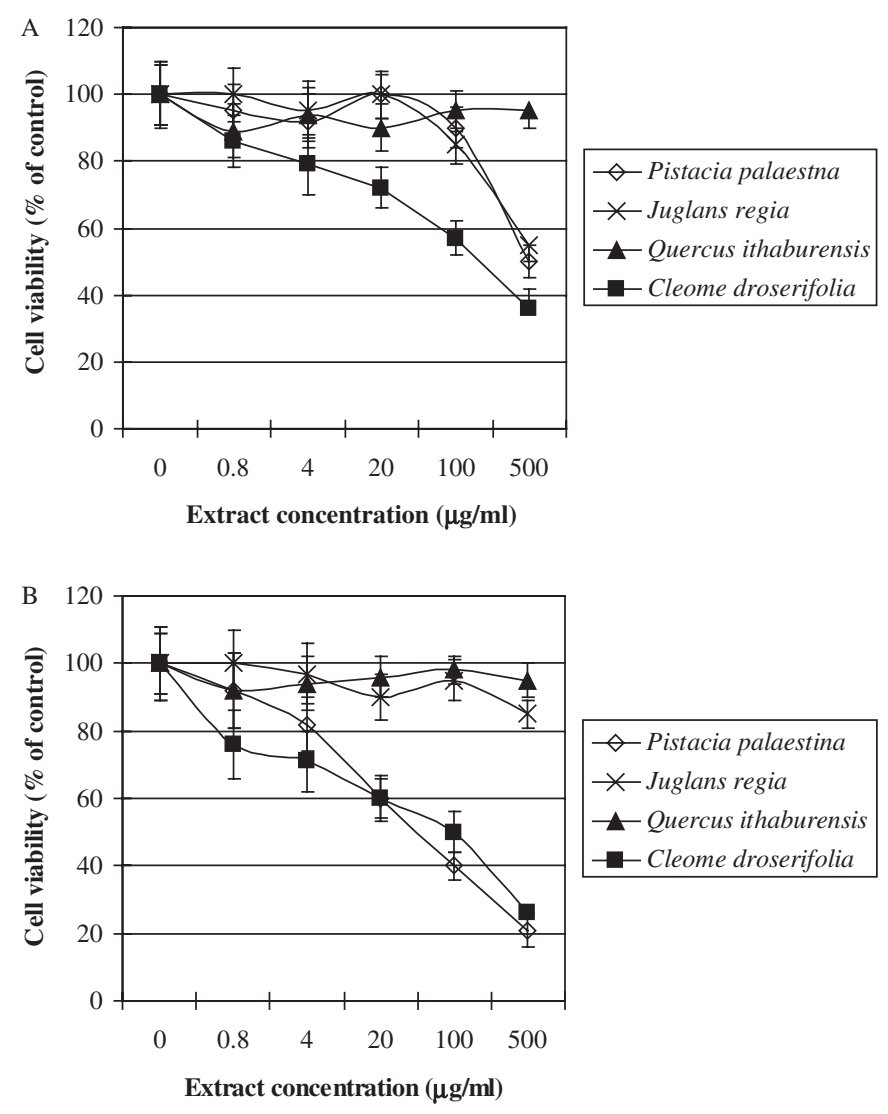

Figure 1. MTT assay in HepG2 cells (A) and in the co-culture of HepG2 and THP1 cells (B) after an overnight incubation with various concentrations of extracts from $P$. palaestina, J. regia, Q. ithaburensis and C. droserifolia (positive control). The absorbance of the MTT formazan was determined at $570 \mathrm{~nm}$ in an ELISA reader. Cell viability was defined as the ratio (expressed as a percentage) of absorbance of treated cells to untreated cells. Values given represent the mean \pm standard deviations of three independent experiments carried out in triplicate.

\section{Evaluation of Effects on Cell Viability Using LDH-Release Test}

Membrane integrity can be evaluated by measuring LDH activity. LDH, an enzyme located in the cytoplasm, catalyses the conversion of lactate and pyruvate. When LDH is found within the media on the cells, there are two possible causes: the first is cellular death and the second may be a 'leak' in a cell membrane. When cells are disrupted, LDH activity is elevated.

\section{HepG2 Cells}

Results obtained in the present in vitro study indicate no significant changes of LDH levels in the culture medium were seen after $24 \mathrm{~h}$ of exposure to extracts from J. regia and Q. ithaburensis (Fig. 2A). Pistacia palaestina extract significantly increased the extracellular LDH levels at concentrations higher than $100 \mu \mathrm{g} \mathrm{ml}^{-1}$ (Fig. 2A). Cell viability was significantly decreased with increasing concentrations of C. droserifolia extract, the positive control.
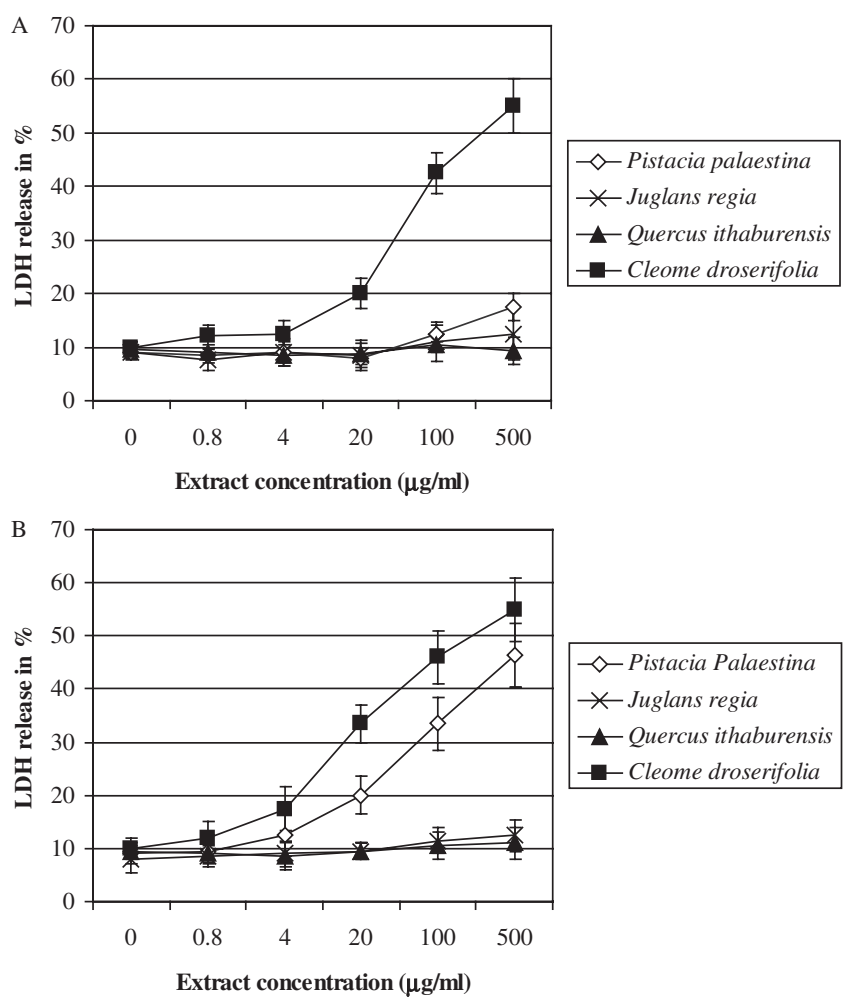

Figure 2. LDH leakage from HepG2 cells (A) and from co-cultures of HepG2 and THP1 cells (B) after overnight incubation with various concentrations of extracts from P. palaestina, J. regia, Q. ithaburensis and C. droserifolia (positive control). The leakage of the cytoplasm located LDH into the extracellular medium is measured. LDH activity was measured in both the supernatants and the cell lysate fractions. Values given represent the mean \pm standard deviations of three independent experiments carried out in triplicate.

\section{Co-cultures of HepG2 with THP1}

As seen with HepG2, LDH levels were not significantly increased after treatment with extracts from J. regia and $Q$. ithaburensis. The effect of $P$. palaestina extract was similar to that found in the MTT assay. Concentrations higher than 20 $\mu \mathrm{g} \mathrm{ml}^{-1}$ significantly increased the extracellular LDH levels reaching about $100 \%$ at the highest concentration tested (Fig. 2B).

\section{Effects on the Biofunctionality of Cultured Cells}

The effects of the three plant extracts on expression of liver specific functions were measured by assessing albumin secretion by HepG2. Levels of albumin in the cell culture medium were unchanged by treatment with any of the three test extracts (data not shown).

\section{Discussions and Conclusions}

Recently, the number of people using medicinal plants has been rapidly increasing and therefore national health authorities are beginning to express concern over the safety 
and efficacy of these products since almost all of them are sold over the counter and are not registered $(18,19)$. The purpose of the present study is to develop a new way to evaluate both biosafety and biofunctionality of herbal extracts.

\section{In vitro Test Methods}

A very sensitive method for testing the toxicity of plant extracts and their degradation products is the assessment of in vitro toxicity. In vitro cell culture methods have the advantage of relatively well-controlled variables and are generally accepted as very effective for biosafety testing. Their sensitivity is equal to or greater than that of in vivo tests. In vitro test methods are based on the extraction of the bioactive compounds. After exposure of cells to extracts, cytotoxicity is assessed by various methods, such as microscopical evaluation of cell morphology, the methyltetrazolium assay (MTT test), measurement of DNA and protein synthesis, LDH activity, and neutral red uptake. However, it has long been realized that while growth in two dimensions is a convenient way of preparing and observing a culture and allows a high rate of cell proliferation, it lacks the cell-cell and cell-substrate interactions characteristic of the whole tissue in vivo. The interactions of a cell with a substratum play an important role not only in the development, differentiation and regeneration of multicellular organisms but also in preserving the specific phenotype of cultured cells in vitro.

\section{Co-cultures of Hepatocytes and Monocytes}

The development of a new in vitro test system that enables cultured cells to grow at higher cell density and to maintain more in vivo like cell-to-cell interactions is very important in order to obtain more reliable results in vitro. Nonparenchymal cells, in particular Kupffer cells, might play an important role in the modulation of xenobiotic metabolism in liver and its pharmacological and toxicological consequences (20). Therefore, we used co-cultures of human hepatoplastoma cell line HepG2 cells and monocyte cell line THP1. HepG2 cell line retains differentiated parenchymal functions of normal hepatocytes and can be grown indefinitely, thus permitting long-term studies to be performed. After treatment of HepG2 cells and co-cultures of HepG2 cells and THP1 cells with various concentrations of extracts of $P$. palestina, $J$. regia and $Q$. ithaburensis for $24 \mathrm{~h}$, the biosafety (MTT and LDH release) and biofunctionality (albumin production) were evaluated.

\section{The Role of Monocyte-derived Mediators}

The observed difference in cytotoxicity of $P$. palaestina extract in hepatocytes and in co-culture of hepatocytes and monocytes may be the result of cell-to-cell interactions and/or of cytokines produced by monocytes. In LPS-induced liver injury, activated hepatic Kupffer cells play an essential role $(21,22)$. Following contact with the cluster of differentiation (CD) 14 protein, the complex triggers a signal cascade involving the nuclear factor kappa B. This factor enhances the expression of inflammation-related genes. The acutephase response is regulated by cytokines released by activated Kupffer cells, notably interleukin-1 (IL-1), interleukin-6 (IL-6) and tumor necrosis factor- $\alpha$ (TNF- $\alpha$ ) (23). Among these cytokines, IL-6, also known as hepatocyte-stimulating factor, is a major inducer of the acute phase response. IL-6 is produced not only by Kupffer cells but also other cell types including monocytes/macrophages, fibroblasts, keratinocytes, endothelial cells, mesanglial cells, chondrocytes, $\mathrm{T}$ cells, B cells, human hepatoma cells (HepG2) and primary human hepatocytes. Hepatocytes also produce nitric oxide (NO) during chronic hepatic inflammation (24) and in vitro in response to conditioned medium from activated Kupffer cells (25) or to a mixture of LPS and TNF- $\alpha$, IL- 1 and IFN- $\gamma$. In the liver, TNF- $\alpha$ production is not restricted to Kupffer cells.

Saad et al. (26) showed that LPS affects the acute phase response via hepatocyte-derived IL- 6 and TNF- $\alpha$ in an autocrine loop and the NO production of parenchymal liver cells. TNF- $\alpha$ is also involved in inducing cell damage by promoting oxidative stress in mitochondria that occurs as a result of an imbalance between oxidants and antioxidants in favor of oxidants (27). TNF- $\alpha$ stimulates the production of reactive oxygen species [ROS and reactive nitrogen species (RNS)]. ROS have been implicated in the pathogenesis of many forms of liver disease. When liver cells are exposed to excess ROS, oxidative stress occurs and affects many cellular functions. However, cells are equipped with antioxidant systems. The essential function of the cellular antioxidant systems is to lower the steady state of intracellular concentrations of free radicals. They are interrelated and fall into two broad categories as follows: enzymatic (e.g. glutathione peroxidase, catalase and superoxide dismutase) and non-enzymatic antioxidant [e.g. vitamin E, vitamin $\mathrm{C}$ and reduced glutathione (GSH)] defenses. It seems that the observed reduction in cell viability in co-cultures is the result of monocyte-derived factors produced after activation of these cells by extract from $P$. palestina. Therefore, cell-cell interactions must be taken into consideration by the in vitro evaluation of medicinal plant biosafety.

\section{Conclusions}

In conclusion, conventional homotypic hepatocyte cultures do not include the possible contribution of non-parenchymal liver cells, particularly Kupffer cells, to the pharmacological and toxicological consequences after exposure to xenobiotics. Results obtained here indicate that co-cultures improve the reliability of data obtained from organ-specific cell cultures and that they more closely stimulate the situation in the intact liver.

\section{References}

1. Said O, Khalil K, Fulder S, Azaizeh H. Ethnobotanical survey of medicinal herbs of the Middle Eastern region. J Ethnopharmacol 2002;83:251-65. 
2. Farnsworth NR, Soejarto DD. Potential consequence of plant extinction in the United States on the current and future availability of prescription drugs. Econ Bot 1985;39:231-40.

3. Soejarto DD. Biodiversity prospecting and benefit-sharing: perspectives from the field. J Ethnopharmacol 1989;51:1-15.

4. Elvin-Lewis M. Should we be concerned about herbal remedies? J Ethnopharmacol 2001;75:141-64.

5. Chan K. Some aspects of toxic contaminants in herbal remedies. A review. Chemosphere 2003;52:1361-71.

6. Ernst E. Harmless herbs? A review of the recent literature. Am J Med 1998;104:170-8.

7. Ernst E. Herbal medications for common ailments in the elderly. Drugs Aging 1999; 15:423-8.

8. Abu-Irmaileh BE, Afifi FU. Herbal medicine in Jordan with special emphasis on commonly used herbs. J Ethnopharmacol 2003;89:193-7.

9. Pak E, Esrason KT, Wu VH. Hepatotoxicity of herbal remedies: an emerging dilemma. Prog Transplant 2004;14:91-6.

10. Saad B, Azaizeh H, Said O. Tradition and perspectives of Arab herbal medicine: a review. Evid Based Complement Alternat Med 2005;2:475-9.

11. El Nahhal Y. Contamination and safety status of plant and food in Arab countries. J Appl Sci 2004;4:411-7.

12. Ventura C. CAM and cell fate targeting: molecular and energetic insights into cell growth and differentiation. Evid Based Complement Alternat Med 2005;2:277-83.

13. Shimazawa M, Chikamatsu S, Morimoto N, Mishima S, Nagai H, Hara H. Neuroprotection by Brazilian green propolis against in vitro and in vivo ischemic neuronal damage. Evid Based Complement Alternat Med $2005 ; 2: 201-7$

14. Saad B, Schawalder HP, Maier P. Crude liver membrane fractions maintain liver specific functions in long term, serum free rat hepatocyte cultures. In Vitro Cell Dev Biol 1993;29:32-40.

15. Saad B, Scholl FA, Thomas H, Schawalder HP, Streit V, Waechter F, et al. Crude liver membrane fractions and extracellular matrix components as substrata regulate differentially the preservation and inducibility of P-450 isoenzymes in cultured rat hepatocytes. Eur J Biochem 1993; 213:805-14
16. Medina-Diaz IM, Elizondo G. Transcriptional induction of CYP3A4 by o,p'-DDT in HepG2 cells. Toxicol Lett 2005;16:41-7.

17. Saad B, Abu-Hijleh G, Suter UW. Polymer biocompatibility assessment by cell culture techniques. In: Arshady $\mathrm{R}$ (ed). The PMB Series Volume 1: Introduction Polymeric Biomaterials. The Citus Books, 2003, 263-99.

18. Cooper EL. Drug discovery, CAM and natural products. Evid Based Complement Alternat Med 2004;1:215-7.

19. Cooper EL. Complementary and alternative medicine, when rigorous, can be science. Evid Based Complement Alternat Med 2004;1:1-4.

20. Milosevic N, Schawalder H, Maier P. Kupffer cell-mediated differential down-regulation of cytochrome $\mathrm{P} 450$ metabolism in rat hepatocytes. Eur J Pharmacol 1999;26:75-87.

21. Knolle P, Lohr H, Treichel U, Dienes HP, Lohse A, Schlaack J, et al. Parenchymal and nonparenchymal liver cells and their interaction in the local immune response. Gastroenterol 1995;33:613-20.

22. Toth CA, Thomas P. Liver endocytosis and Kupffer cells. Hepatology 1992;16:255-66.

23. Ramadori G, Armbrust T. Cytokines in the liver. Eur J Gastroenterol Hepatol 2001;13:777-84.

24. Billiar TR, Curran RD, Harbrecht BG, Stuehr DJ, Demetris AJ, Simmons RL. Modulation of nitrogen oxide synthesis in vivo: $N^{\mathrm{G}}$ monomethyl-L-arginine inhibits endotoxin-induced nitrite/nitrate biosynthesis while promoting hepatic damage. J Leukoc Biol 1990;48: 565-9.

25. Curran RD, Billiar TR, Stuehr DJ, Hofmann K, Simmons RL. Hepatocytes produce nitrogen oxides from L-arginine in response to inflammatory products of Kupffer cells. J Exp Med 1989;170:1769-74.

26. Saad B, Frei K, Scholl F, Fontana A, Maier P. Hepatocyte-derived IL-6 and TNF-a mediate the LPS-induced acute phase response and NO-release by cultured rat hepatocytes. Eur J Biochem 1995;229: 349-55.

27. Sies H. Oxidative stress: oxidants and antioxidants. Exp Physiol 1997;82: 291-5.

Received June 14, 2005; accepted January 17, 2006 


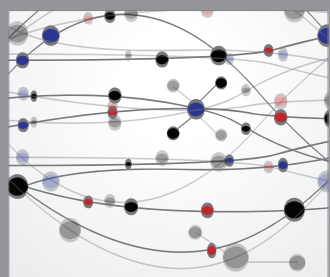

The Scientific World Journal
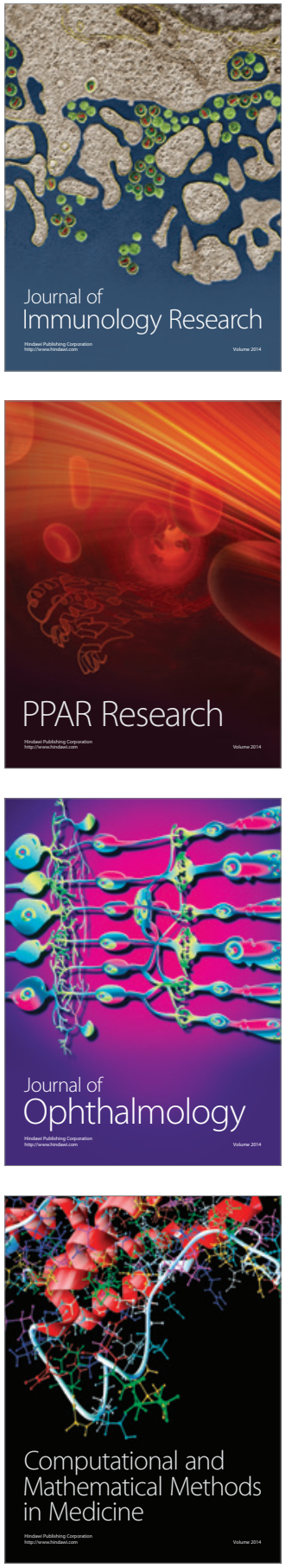

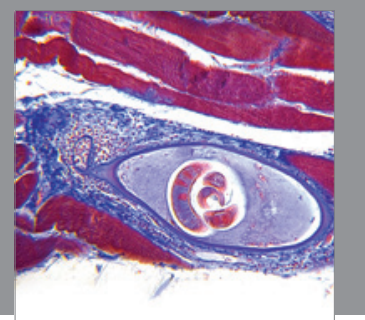

Gastroenterology

Research and Practice
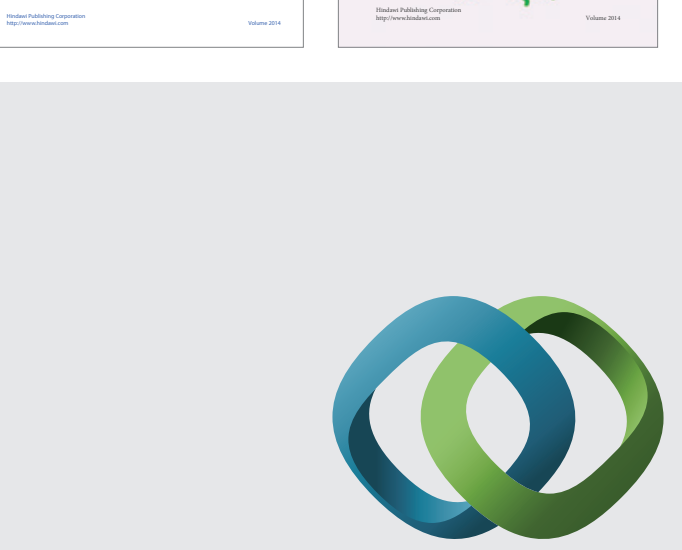

\section{Hindawi}

Submit your manuscripts at

http://www.hindawi.com
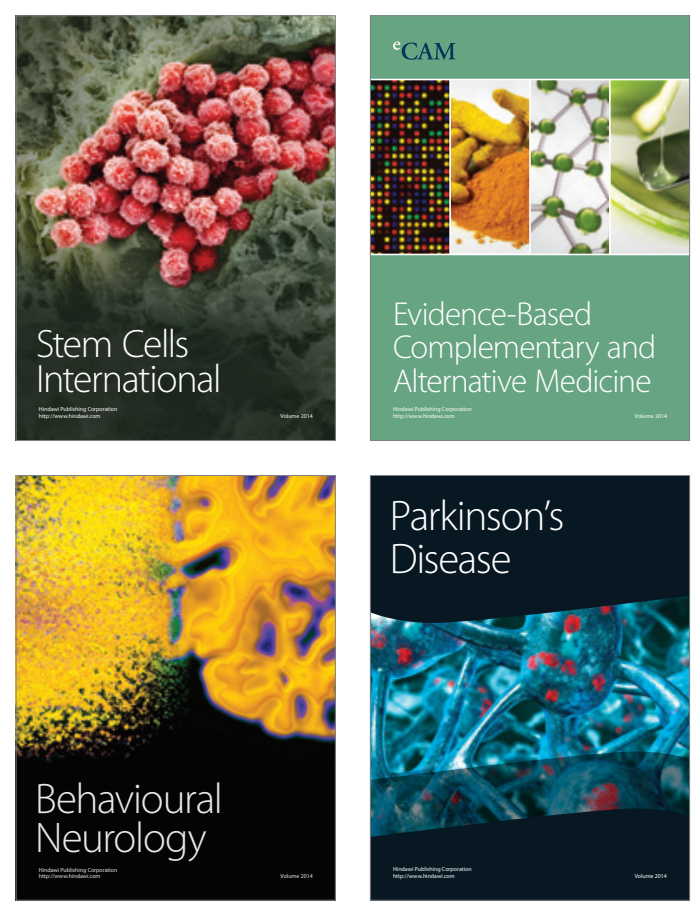

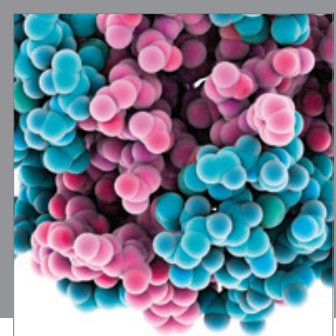

Journal of
Diabetes Research

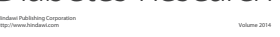

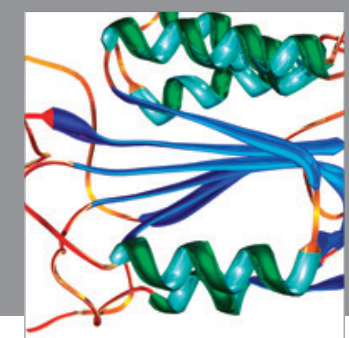

Disease Markers
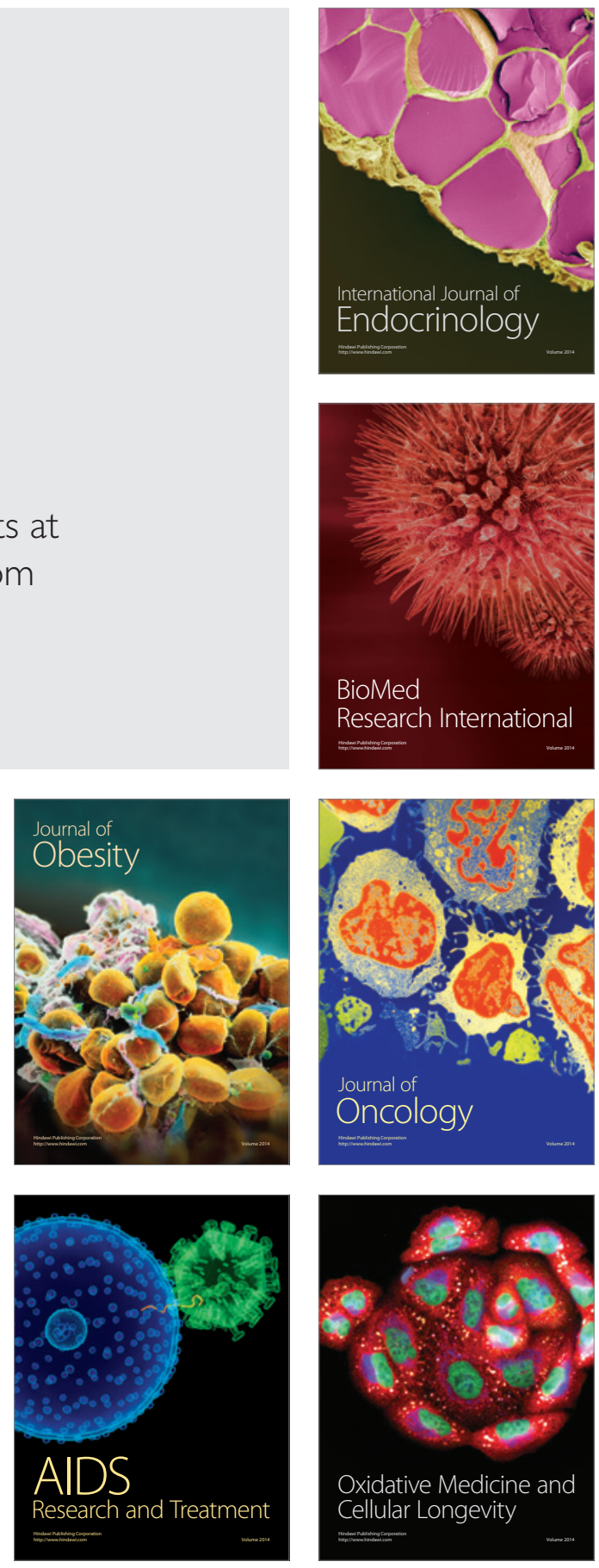